\title{
Construction and Expression of L-Arabinose Isomerase (L-AI) in Cell- Surface of Pichia pastoris
}

\author{
Agnes Yuliana\#, Hariyatun", Asrul Muhammad Fuad", Antonius Suwanto", and Wien Kusharyoto* \\ ${ }^{\#}$ Biotechnology Study Program, Postgraduate School, Bogor Agricultural University, Bogor, 16680, Indonesia \\ E-mail: agnes.yuliana07@gmail.com
}

*Research Center for Biotechnology, Indonesian Institute of Sciences, Cibinong, 16911, Indonesia

E-mail:wien.kyoto@gmail.com

\begin{abstract}
A gene encode L-arabinose isomerase ( $\mathrm{L}$-AI). It is an enzyme converting D-galactose to D-tagatose. D-tagatose is is a hexoketose monosaccharide sweetener, which is an isomer of D-galactose and rarely found in nature. It is a potential sweetener which has low calorie. The aim of this study is to construct $\operatorname{araA}$ gene in the expression vector pJ912-AG $\alpha$ and expression the protein in the cell-surface of Pichia pastoris GS115. Both vector pJ912-AG $\alpha$ and araA gene was digested with SalI and Kpn2I restriction enzymes then was ligated. The ligation solution had been successfully introduced into Escherichia coli DH5a. Vektor pJ912-AGa-araA was successfully integrated into the genome of $P$. pastoris GS115. Genetically stable transformed cells have been obtained after selection on zeocin medium up to $1000 \mu \mathrm{g} / \mathrm{mL}$ zeocin. We had successfully syntheized L-AI protein in the $P$. pastoris GS115. Observation using fluorescence microscopy has proven that successful transformaned cell emit green fluorescence derived from the interaction of functional His6 protein and rabbit polyclonal to $6 \times \mathrm{His} \mathbf{t a g}^{\circledR}$ and showed that L-AI protein was expressed successfully in cell-surface of P.pastoris.
\end{abstract}

Keywords—araA; L-Arabinose isomerase; Yeast surface display; Pichia pastoris

\section{INTRODUCTION}

D-Tagatose is a hexoketose monosaccharide sweetener, which is an isomer of D-galactose and rarely found in nature [1]. It occurs naturally in small quantities in Sterculia setigera gum, and it is also found in dairy products [2], [3]. The sweetness of D-tagatose is $92 \%$ of sucrose. This sugar has no cooling effect or aftertaste and is involved in browning reaction. The taste and properties of this sugar are similar to those of sucrose. In addition, it has zero available calory, no laxative effect, and toothfriendly property [4]. Thus, D-tagatose can be used as a low-calorie sweetener in a wide variety of foods, beverages, health foods, and dietary supplements [5].

Recently, there has been great interest in the biological manufacture of D-tagatose from D-galactose. Several enzymes involved in the biotransformation of D-tagatose have been investigated [6]-[9]. L-arabinose isomerase (L-AI) is considered to have the most potential use for D-tagatose production, since it can catalyze the isomerization of Dgalactose to D-tagatose and convert L-arabinose to Lribulose, based on the similarity in configuration of the substrates [10].
Thermophilic L-AI has been reported possessing a catalytic activity for conversion of D-galactose to D-tagatose. Generally, isomerization process performed at high temperature $\left(>70^{\circ} \mathrm{C}\right)$ offers several advantages, such as higher conversion yield, faster reaction rate, and lower viscosity of the substrate in the product stream [11]. Many research have reported the thermophile L-AI producing bacteria, i.e. Bacillus stearothermophilus US100 [12], Geobacillus stearothermophilus [13], G. thermodenitrificans [14], Thermus sp. [15], Thermoanaerobacter mathranii [16], Bacillus coagulans [17], Enterococcus faecium [18], Thermotoga maritime [19], and the acidic L-AI from Alicyclobacillus acidocaldarius [20]. Moreover, those of LAIs had been purified and characterized. L-AI from $G$. stearothermophilus (GSAI) has the highest level of tagatose production and productivity. The production of tagatose is about $230 \mathrm{~g} / \mathrm{L}$ [21] and the productivity is about $54 \mathrm{~g} / \mathrm{L} / \mathrm{h}$ [22] using a bioreactor containing immobilized GSAI. These results approach commercial production criteria.

Cell surface display allows expression of proteins or peptides on the surface of cells in a stable manner, using the surface proteins of phage [23] [24], bacteria [25] [26], yeast [27-28], or even mammalian cells [29] as anchoring motifs. The first surface display was developed in the mid- 
1980s by Smith, who displayed peptides and small proteins on the surface of a bacteriophage [30]. Cell-surface display is a novel technique which is widely used for development a whole cell biocatalyst [31][32]. This system utilize the cell as a carrier for immobilized enzyme [33], i.e. the protein interest which is fused to the cell wall protein, thus the strain developed produces the enzyme as a fused protein to the cell wall [34]. Biocatalyst production via cell-surface display potent to be the most cost-effective method because there is no need for cell disruption, protein purification and enzyme immobilization. In fact, by growing and inducing the host cells, the enzyme will be produced as an immobilized protein on cell-surface and harvested cell could be directly used as biocatalyst. Enzyme-displaying cell may be reused several times as biocatalyst [35].

Yeast cell-surface display system was first described for Saccaromyces cerevisiae [36]. Recently, the methylotropic yeast Pichia pastoris has also been employed as a host for cell-surface display [37]. The major advantages of $P$. pastoris over $S$. cerevisiae as a cellular host include prevention of hyperglycosylation, integration of multicopy of transforming DNA into genomic DNA and formation of stable transformants, and its higher protein production [38]. The cell-surface display system for $P$. pastoris was first reported in the work of fused Kluyveromyces yellow enzyme to the C-terminal half of $S$. cerevisiae $\alpha$-agglutinin which is displayed on $P$. pastoris cell-surface [39]. Many proteins have been expressed in the surface cell of $P$. pastoris, including Lipase B from Candida Antarctica [40], Lipase from Rhizopus orizae [41], mPmRab7 and pVP28 protein [42].

Here in, we constructed a $P$. pastoris cell-surface display system based on $S$. cerevisiae $\alpha$-agglutinin cell wall protein and studied cell-surface display of GSAI by $P$. pastoris.

\section{MATERIALS AND METHODS}

\section{A. Strains and growth media}

The E. coli DH5a strain (Invitrogen) was used as a host for DNA manipulations. The strain was cultured in low salt Luria Bertani (LSLB) medium (1\% tryptone, $0.5 \% \mathrm{NaCl}$, and $0.5 \%$ yeast extract plus $2 \%$ agar in plates) by using 25 $\mu \mathrm{g} / \mathrm{mL}$ zeocin (Invitrogen) for the selection of transformants. The $P$. pastoris GS115 strain (His4, AOX1) (Invitrogen) was routinely cultured in YPD medium (1\% yeast extract, $2 \%$ peptone, and $2 \%$ dextrose plus $2 \%$ agar in plates), and supplemented with $1 \mathrm{M}$ sorbitol and $100 \mu \mathrm{g} / \mathrm{mL}$ zeocin for the selection of transformants.

\section{B. Construction of the expression vector}

The complete open reading frame of GSAI coding gene ( $\operatorname{araA}$ ) was PCR-amplified by Platinum Tag DNApolymerase (Invitrogen) using pET21b-GSAI as template. Primers were design according to the sequence of $\operatorname{araA}$ gene and multiple cloning site of pJ912-AG $\alpha$. The araA gene was amplified by PCR using the primers PPAI_F: 5'GCGTCGACATGCATCACCATCACCATCACATGCTGTCATT ACGTCCTTATGAATTTGG-3' (contains SalI restriction site at the 5'-end and polyhistidine (6×His) tag) and PPAI_R: 5'GTCACTCCGGACCGCCCCCGCCAAAATACTTCATTCCATC3' (contains Kpn2I restriction site at 5'-end) with the following programs: initial denaturation for $2 \mathrm{~min}$ at $94^{\circ} \mathrm{C}$; followed by 35 cycles of denaturation for $30 \mathrm{~s}$ at $95^{\circ} \mathrm{C}$, annealing for $30 \mathrm{~s}$ at $60^{\circ} \mathrm{C}$, and extention for $2 \mathrm{~min}$ at $72^{\circ} \mathrm{C}$; and final extension for $5 \mathrm{~min}$ at $72^{\circ} \mathrm{C}$. The resultant PCR products were digested with SalI and Kpn2I, and cloned into pJ912-AG $\alpha$ vector by using T4 ligase (Thermo Scientific), respectively. The resultant plasmids were named as pJ912$A G \alpha-\operatorname{araA}$.

\section{Transformation of E. coli DH5a}

The pJ912-AG $\alpha$-araA was used for transformation of $E$. coli DH $5 \alpha$ by heat shock method. The transformantion mix was spread on LSLB agar medium containing $25 \mu \mathrm{g} / \mathrm{mL}$ zeocin, and incubated overnight at $37^{\circ} \mathrm{C}$. After transformation, each colony was cultured into $2 \mathrm{~mL}$ LSLB medium containing $25 \mu \mathrm{g} / \mathrm{mL}$ zeocin overnight at $37^{\circ} \mathrm{C}$ with shaking at $250 \mathrm{rpm}$. Further, plasmid DNA from each culture was isolated by miniprep technique using QIAprep spin miniprep kit (Qiagen). The authenticity of the recombinant plasmid was confirmed by restriction analysis, PCR analysis and sequencing (1st BASE, Selangor, Malaysia) [43].

\section{Transformation of $P$. pastoris and selection of transformants}

Single colony of $P$. pastoris GS115 was cultured into 100 $\mathrm{mL}$ YPD mediumat $30^{\circ} \mathrm{C}$ with shaking at $250 \mathrm{rpm}$ until an $\mathrm{OD}_{600}$ of 1.3. The cells were then centrifuged at $5000 \mathrm{rpm}$ for $5 \mathrm{~min}$ at $4^{\circ} \mathrm{C}$, and the pellets were washed with $25 \mathrm{~mL}$ ice-cold sterile milli-Q water. This washing step was repeated twice. Further, the pellets were resuspended with $200 \mu \mathrm{L}$ ice-cold sterile $1 \mathrm{M}$ sorbitol medium.

The yeast expression library vectors were linearized by SacI digestion and used for transformation of $P$. pastoris GS115 by electroporation method described in EasySelect Pichia expression kit user manual (Invitrogen). A $20 \mu \mathrm{g}$ purifed plasmid was digested with $100 \mathrm{U}$ of $\mathrm{SacI}$ at $37^{\circ} \mathrm{C}$ overnight. A $80 \mu \mathrm{L}$ GS115 cells were then mixed with approximately 5-10 $\mu \mathrm{g}$ SacI-linearized pJ912-AG $\alpha$-araA plasmid, and subsequently transferred to an ice-cold $0.2 \mathrm{~cm}$ electroporation cuvette (Bio-Rad, Hercules, California, USA) and incubated on ice for $5 \mathrm{~min}$. Electroporation process was performed by using Genepulser electroporation system (BioRad, Hercules, California, USA) and the manufacture setting for $P$. pastoris was used, i.ee. under the following conditions: $1977 \mathrm{~V}, 25 \mu \mathrm{F}, 200 \Omega$, and $4.5 \mathrm{~ms}$. Immediately after the pulse, $150 \mu \mathrm{L}$ ice-cold sterile 1.M sorbitol was added to the cuvette, and the solution was then transferred to $1.5 \mathrm{~mL}$ tube and incubated for $60 \mathrm{~min}$ at $30^{\circ} \mathrm{C}$. After that, $100 \mu \mathrm{L}$ YPD medium was added to the tube and incubated for $120 \mathrm{~min}$ at $30^{\circ} \mathrm{C}$. The cells were plated onto YPDS agar medium $(1 \%$ yeast extract, $2 \%$ peptone, $2 \%$ glucose, $2 \%$ Bacto agar, and 1 M sorbitol) containing $100 \mu \mathrm{g} / \mu \mathrm{L}$ zeocin in 5 different quantities of culture which are 25,50 , and $100 \mu \mathrm{L}$. The plates were incubated at $30^{\circ} \mathrm{C}$ for $4-10$ days. Zeocin-resistant clones were picked up and transferred to YPD agar medium containing 200, 500 and $1000 \mu \mathrm{g} / \mathrm{mL}$ zeocin for determination of the copy number of integrants. The subsequent comparisons of secreted proteins were only made between transformants with approximately the same copy number as determined by the same concentration range of 
drug resistance against zeocin. Zeocin-resistant clones were PCR-screened for integration of the plasmid construction into the yeast genome.

\section{E. Purication of chromosomal DNA from P. pastoris GS115 transformants}

The method which was used to purify the chromosomal DNA from the yeast was based on the smash and grab DNA miniprep method [5]. Colonies of the transformants were replated onto YPD agar medium containing $100 \mu \mathrm{g} / \mu \mathrm{L}$ zeocin and incubated for 2 days at $30^{\circ} \mathrm{C}$. A $5 \mathrm{~mm}$ diameter glass beads were washed in $30 \% \mathrm{HCl}$, and subsequently milli-Q water, and autoclaved. A breaking buffer, composing of $10 \mathrm{mM}$ Tris buffer at $\mathrm{pH} 8.0,1 \mathrm{mM}$ EDTA at $\mathrm{pH} 8.0,100$ $\mathrm{mM} \mathrm{NaCl}, 1 \% \mathrm{SDS}$, and $2 \%$ Triton $\mathrm{X}-100$, was prepared. A $10 \mathrm{~mL}$ culture of $P$. pastoris GS115_pJ912-AG $\alpha$-araA was grown overnight at $30^{\circ} \mathrm{C}$, and the cells were then harvested by centrifugation at $5000 \mathrm{rpm}$ for $2 \mathrm{~min}$ at room temperature. The cells were placed in an eppendorf tube and resuspended in $200 \mu \mathrm{L}$ breaking buffer and $200 \mu \mathrm{L}$ PCI (phenol, chloroform, and isoamyl alcohol), and $0.25 \mathrm{~g}$ glass beads were then added. The tube was then vortexed at top speed for $10 \mathrm{~min}$ at room temperature. A $200 \mu \mathrm{L}$ TE buffer (10 $\mathrm{mM}$ Tris at $\mathrm{pH} 8.0$ and $1 \mathrm{mM}$ EDTA at $\mathrm{pH} 8.0$ ) was added, and the tube was vortexed for $10 \mathrm{sec}$. The tube was then centrifuged at $10.000 \mathrm{rpm}$ for $10 \mathrm{~min}$ at room temperature. The aqueous phase was added to a fresh eppendorf tube, and the DNA was precipitated using ethanol precipitation method. The pellets obtained through the precipitation were resuspended in $50 \mu \mathrm{L}$ DNA/RNAse free water.

\section{$F$. Expression of recombinant P. pastoris clones}

A $100 \mathrm{~mL}$ of buffered glycerol-complex medium (BMGY,

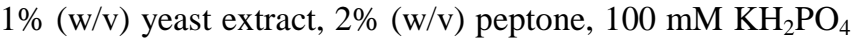
at $\mathrm{pH} 6.0,1.34 \%(\mathrm{w} / \mathrm{v})$ yeast nitrogen base without amino acids, $4 \times 10^{-5} \%(\mathrm{w} / \mathrm{v})$ biotin, and $1 \%$ glycerol (w/v)) was inoculated using a single colony in a $250 \mathrm{~mL}$ flask. The flask was incubated at $30^{\circ} \mathrm{C}$ in a shaking incubator at $200 \mathrm{rpm}$ until an $\mathrm{OD}_{600}$ of 3 . The cells were then harvested by centrifugation at $3000 \times \mathrm{g}$ for $5 \mathrm{~min}$ at room temperature, and resuspended in buffered methanol-complex medium (BMMY, the same media as BMGY but $1 \%$ methanol (v/v) replaced for glycerol) to an $\mathrm{OD}_{600}$ of 10 . The flask was then covered with 2 layers of sterile gauze, and incubated at $25^{\circ} \mathrm{C}$ in a shaking incubator at $200 \mathrm{rpm}$. To maintain induction, $100 \%$ methanol was added to the culture to a final concentration of $0.5 \%$ every 24 h. $\quad P$. pastoris GS115/His ${ }^{+} \mathrm{Mut}^{+}$Albumin (Invitrogen) strains were included in expression experiments and used as negative control, respectively. Samples of culture were taken after $72 \mathrm{~h}$ and analyzed for expression.

\section{G. Immunofluoresence microscopy analysis}

Portions $(10 \mu \mathrm{L})$ of cell cultures were added to $500 \mu \mathrm{L}$ of TBS (50 mM Tris- $\mathrm{HCl}, 150 \mathrm{mM} \mathrm{NaCl}[\mathrm{pH}$ 7.5]) and centrifuged for $3 \mathrm{~min}$ at $5000 \times \mathrm{g}$ at $4^{\circ} \mathrm{C}$. Pellets were resuspended in $200 \mu \mathrm{L}$ of TBS and $3 \mu \mathrm{g}$ of specific, FITCconjugated rabbit polyclonal antibody to $\mathrm{His}_{6}$ tag (Abcam) was added to the suspensions, followed by incubation for $2 \mathrm{~h}$ at room temperature with constant shaking at $100 \mathrm{rpm}$. The cell were then washed with $200 \mu \mathrm{L}$ of $0.1 \%$ TBST and resuspended in $300 \mu \mathrm{L}$ of TBS [44]. For immunofluoresence microscopy, slides were prepared from $10 \mu \mathrm{L}$ of cell suspensions, and observed by Zeiss Axio Imager.Z2 fluorescence microscope (Zeiss, Oberkochen, Germany).

\section{H. Immunomagnetic screening analysis}

Portions $(25 \mu \mathrm{L})$ of cell cultures were placed in a microtube $1.5 \mathrm{~mL}$ with $25 \mu \mathrm{L}$ Pure Proteome ${ }^{\mathrm{TM}}$ Nickel Magnetic Beads (Milipore Corporation, Billerica; Massachusetts, USA). After vortexing, the sample was incubated at room temperature rotating slowly for $1 \mathrm{~h}$ to allow attachment of $P$. pastoris recombinant to the magnetic beads. Following incubation, the beads were separated from the cell suspension using magnetic particle concentrator. The residual liquid was pipetted off and the beads were washed with binding buffer solution. The sampel was rotated slowly for $10 \mathrm{~min}$ at room temperature. This washing step was repeated two times. The magnetic beads were finaly resuspended in $150 \mu \mathrm{L}$ of binding buffer and detected using either cultural immunofluorescence techniques as described previously.

\section{Extraction and Analysys of cell surface protein}

Cell cultures were collected by centrifugation and washed with buffer A (20 mM Tris- $\mathrm{HCl} \mathrm{pH} 7.5,20 \mathrm{mM} \mathrm{NaCl}$, and 5 $\left.\mathrm{mM} \mathrm{MgCl}_{2}\right)$. Washed cells were incubated with Cellic ${ }^{\circledR}$ Ctec2 (Novozymes, Krogshoejvej, Bagsvaerd, Denmark) in $100 \mathrm{mM}$ sodium acetate buffer, $\mathrm{pH} 5.2$ at room temperature for $24 \mathrm{~h}$ by gently agitation. Extracted protein were precipitated using Acetone and These precipitated protein were stored at $-20^{\circ} \mathrm{C}$ and prepared for SDS-polyacrylamide gels and western blot analysis.

\section{J. SDS-Polyacrylamide Gels}

Portions $(10 \mu \mathrm{L})$ of precipitated protein were added to 10 $\mu \mathrm{L}$ of Laemli buffer and were placed in a $100^{\circ} \mathrm{C}$ (boiling) water bath for $5 \mathrm{~min}$. Proteins were separated by SDSpolyacrylamide gel electrophoresis (SDS-PAGE) according to the method of Laemmli [45] on $12 \%$ polyacrylamide gels.

\section{RESULTS AND DISCUSSION}

\section{A. PCR and recombinant strain development}

L-AI encoding gene (araA) from G. stearothermophilus. The marine bacterial strain G. stearothermophilus isolated from Tanjung api, Poso was found in the sea around a mountain. This bacterium lives at high temperature, so that it has potency to produce a thermophile L-AI [46]. Generally, isomerization is performed at high temperature, so that thermophile L-AI is suitable for this process. Isomerization at high temperature offers several advantages, such as higher conversion yield, faster reaction rate, and lover viscosity of the substrate [11]. Previous study of L-AI from $G$. stearothermophilus (GSAI) found that GSAI is suitable for commercial production of D-tagatose because it has high conversion of D-galactose to D-tagatose [21, 22].

araA was cloned using PCR technique. The primers were designed base on the sequence of $\operatorname{araA}$, and containing restriction-enzyme sites at the end of encoding sequence for insertion into expression vector pJ912-AG $\alpha$. To obtain highly stable expression strain, expression vectors are 
usually integrated into the genome of $P$. pastoris [47]. $P$. pastoris has the following main advantages: first, extremely high yield of intercellular protein; second, very high levels of secretion into an almost protein-free medium; third, ease of fermentation to high cell density; and fourth, genetic stability and scale-up without loss of yield [48]. In this study, we used pJ912-AG $\alpha$ as - expression vector. The pJ912-AG $\alpha$ encoding Sh ble gene from Streptoalloteichus hindustanus, coding for a zeocin resistance protein. Zeocin can be used for selection in E. coli and P. pastoris. This vector is based on strong, methanol inducible AOX1 promoter and terminator spaced by a multiple cloning site for cloning of the gene of interest. Targeted integration of this plasmid into the AOX1 genomic locus is promoted by linearization of the vector within the AOX1 promoter region. Nonetheless, linearization at the AOX1 terminator is also an option [49]. A pUC origin of replication in this vector enables plasmid replication and maintenance in E. coli. This vector is also available with $\alpha$ factor signal peptide, for production secreted recombinant protein, and $A G \alpha$ gene encoding $\alpha$ agglutinin for anchoring protein on the cell-surface (DNA 2.0). There are many advantages with anchoring protein on the cell surface, in which protein are genetically displayed on the cell surface, are easy reproduction of the displayed biocatalysts and easy separation of product from catalyst.

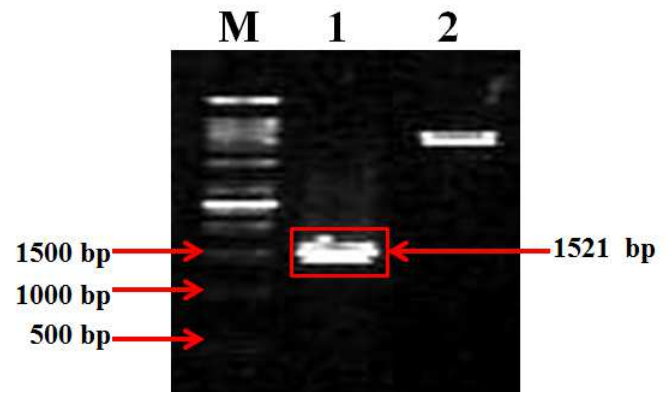

Fig. 1 Result of isolation and PCR amplification on araA gene. Lane M: Marker; Lane 1: Amplification of araA gene; 2: pET21b-GSAI

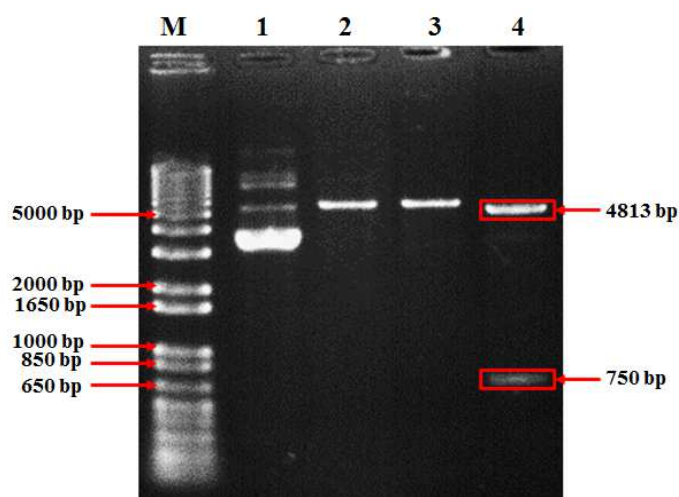

Fig. 2 Restriction analysis of pJ912-AG $\alpha$. Lane M: Marker, Lane 1:

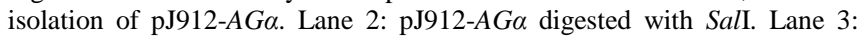
pJ912-AG $\alpha$ digested with Kpn2I. Lane 4: pJ912-AG $\alpha$ digested with SalI and Kpn2I.

Plasmid construction was perfomed to obtain the recombinant plasmid carrying araA gene. The araA gene was first amplified using pET21b-GSAI as template and result showed only single band was estimated size of 1521 bp (Fig. 1). The expression vector was prepared by digestion of pJ912-AG $\alpha$ using SalI and Kpn2I restriction enzymes (Fig. 2). The $\operatorname{ara} A$ gene was also digested using the same enzymes (figure not shown). $\operatorname{araA}$ gene was inserted in pJ912-AG $\alpha$ vector. Then the construct was subsequently transformed into competent $E$. coli DH5 $\alpha$ cells and cultured in LSLB media containing zeocin $25 \mu \mathrm{g} / \mathrm{mL}$. Insertion of araA gene into vector $\mathrm{pJ} 912-A G \alpha$ resulted in around 25 colonies (Fig. 3 ). In addition, some colonies as positive control were obtained. The resultant colonies were evaluated for the true insert size by two different enzymatic digestions, PCR on colony extracted plasmids and DNA sequencing analyses.

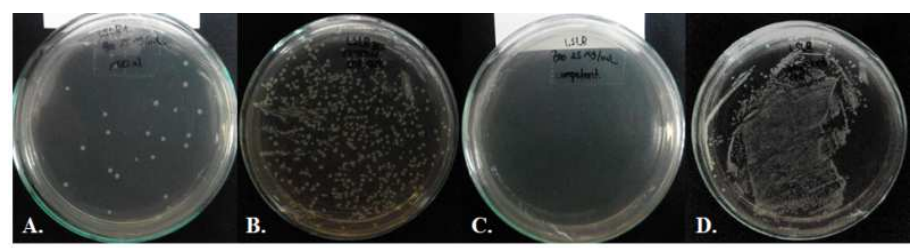

Fig. 3 E. coli transformant colonies. A. E. coli with pJ912-AG $\alpha$-araA; B: E. coli with pJ912-AG $\alpha$ uncut; C: control negatif; D: control positive

The recombinant plasmid obtained was named pJ912$A G \alpha-\operatorname{araA}$. Restriction analysis was carried out determine the actual size of expression vector and insert DNA. Fig. 4 showed restriction of recombinant plasmid using SalI and NcoI enzymes, resulting DNA bands with size of $6334 \mathrm{bp}$ with single restriction, $3412 \mathrm{bp}$ and $2992 \mathrm{bp}$ in double restrictions (Fig. 4) which corresponded to the theoretical size of insert DNA and expression vector.

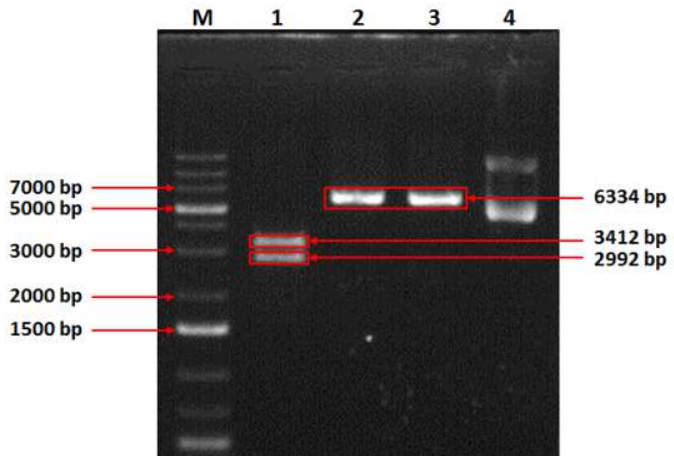

Fig. 4 Restriction analyses of pJ912-AG $\alpha$-araA. Line M: Marker; Line 1 pJ912-AG $\alpha$-araA restriction using SalI and NcoI; Line 2: pJ912-AG $\alpha$-araA restriction using SalI; Line 3: pJ912-AG $\alpha$-araA restriction using NcoI; Line 4: pJ912-AG $\alpha$-araA uncut.

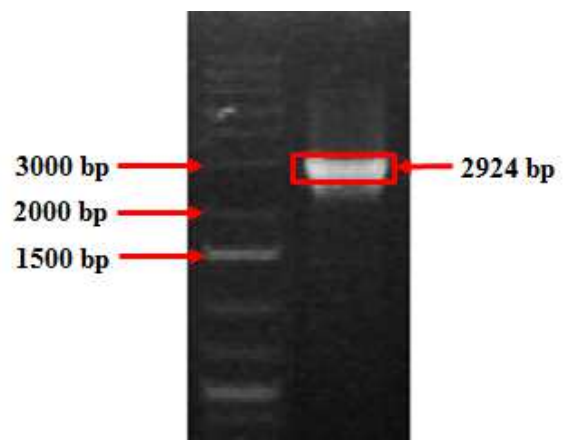

Fig. 5 PCR analysis of pJ912-AG $\alpha$-araA using AOXI primers.

The PCR analysis was perform using AOXI primers. These primers were used to determine the construct of gene within the pJ912-AG $\alpha$ plasmid. Thus, the PCR product would consist of AOX promoter, $\alpha$ factor signal peptide, and $\operatorname{araA}$ gene. Fig. 5 showed a DNA band of approximately 
2924 bp, which corresponds to the theoretical size of desirable fragment. Based on DNA sequencing analysis (data not shown), there was no mutation in DNA encoding L-AI. After all of analyses conducted, it could be concluded that the recombinant plasmid was successfully constructed (Fig 6.).

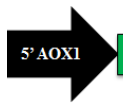

Fig. 6 Scematic description of gene fusion construct pJ912-AG $\alpha$-araA plasmid. 5'AOXI: promoter for alcohol oxidase gene; $\alpha$-factor: $S$. cerevisiae-derived secretion signal sequence; His 6 : polyhistidine tag; araA:gene encoding L-arabinose isomerase; FlagTag: enterokinase restriction site; $A G \alpha$ : C-terminal half of $A G \alpha$ gene; Stop: stop codon; AOXI TT: translation terminator sequence.

\section{B. Transformation of P. pastoris GS115 with pJ912-AG $\alpha$ - $\operatorname{araA}$}

$P$. pastoris-compatible vectors are designed for homologous integration into AOXI locus. Linier DNA can generate stable transformants of $P$. pastoris via integration or homologous recombination between the transforming DNA and region of homology within the genome [50].Recombinant plasmid is integrated into the genome of $P$. pastoris via the mechanism of homologous recombination by utilizing the AOXI promoter sequence similarity between $P$. pastoris genome and vector pJ912-AG $\alpha$. Therefore, before transformation of yeast cells for protein production, restriction mapping was carried out by using restriction enzyme SacI (Fig. 7). For creating a stable recombinant, homologous regions between pJ912-AG $\alpha$-araA and yeast genome were applied. Recombinant plasmid linearization process is one of important things in the transformation of $P$. pastoris because linearized recombinant plasmid can stimulate the recombinant plasmid recombination when plasmid is integrated into the genome of $P$. pastoris.

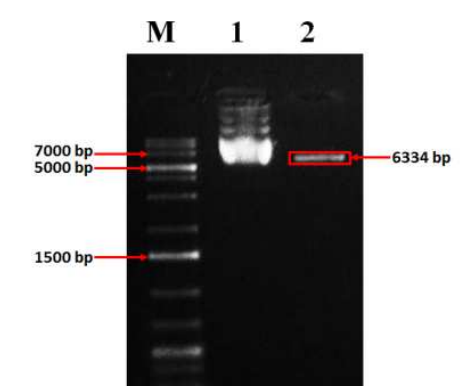

Fig. 7 Restriction analysis of pJ912-AG $\alpha$-araA. Lane M: Marker; Lane 1: pJ912-AG $\alpha$-araA uncut; Lane 2: pJ912-AG $\alpha$ digested with $S a c I$.

The linear recombinant plasmid was transformed into yeast cells by electroporation, so that the recombinant plasmid could be stably integrated into the yeast genome and express the protein. The principle of electroporation method is to use an electric shock to enlarge the pores of the cell membrane, thus increasing membrane permeability. An electrical signal will induce enlargement of the membrane pores, so that the molecules of DNA can enter the cell The transformation process yielded 107 individuals transformed colonies (Fig. 8). Cell-growth state, cell density, incubation time, medium used influence the transformation efficiency.

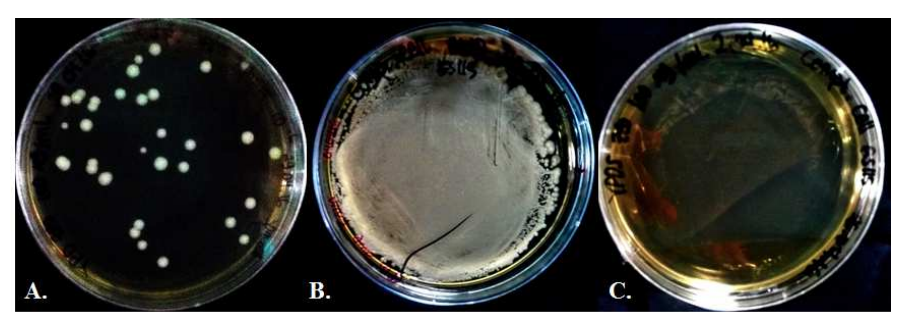

Fig. 8 P pastoris tansformant cells. A: P. pastoris with pJ912-AG $\alpha$-araA; B: control positive; $\mathrm{C}$ : control negative

Some expression vector for Pichia can increase the number of gene copies in $P$. pastoris, so that the amount if expressed protein will be higher. The pJ912-AG $\alpha$ vector also carries zeocin resintance gene, so that the selection of transformants carrying multiple copies of integrated vector can be conducted. Genetic stability analysis were selected from single colonies growing on YPD agar medium containing 100, 200, 500, and $1000 \mu \mathrm{g} / \mathrm{mL}$ zeocin, respectively (Fig. 9). YPD agar medium without zeocin was also used as control. Fig. 6 showed that all colonies look stable in medium with zeocin up to $1000 \mu \mathrm{g} / \mathrm{mL}$. Assuming that the Sh ble gene is incorporated in the same ratio as the AOXI TT sequence, an estimated 1 copy (minimum) of the gene $S h$ ble zeocin resistance is required for grow at 100 $\mu \mathrm{g} / \mathrm{mL}$ zeocin, 4 copies at $500 \mu \mathrm{g} / \mathrm{mL}, 9$ copies at 1000 $\mu \mathrm{g} / \mathrm{mL}$ and clones with as many as 17 copies of gene are found from medium with highest antibiotic concentration of $2000 \mu \mathrm{g} / \mathrm{mL}$ [51]. Colony PCR was conducted toward the transformants to verify if the expression cassette had been integrated into the AOX1 gene (Fig. 10)

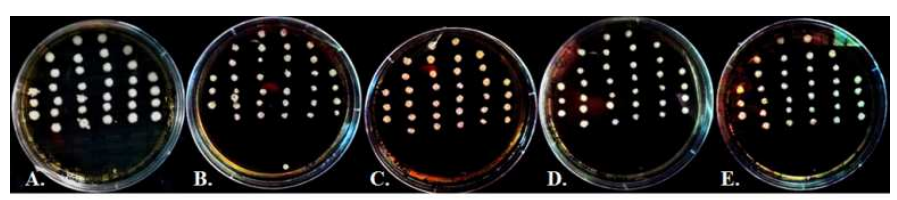

Fig. 9 Screening of genetically stable transformed yeast cells on zeocin plates containing various concentration of zeocin. A: $0 \mu \mathrm{g} / \mathrm{mL}$ (as control); B: $100 \mu \mathrm{g} / \mathrm{mL}$; C: $200 \mu \mathrm{g} / \mathrm{mL}$; D: $500 \mu \mathrm{g} / \mathrm{mL}$; E: $1000 \mu \mathrm{g} / \mathrm{mL}$.

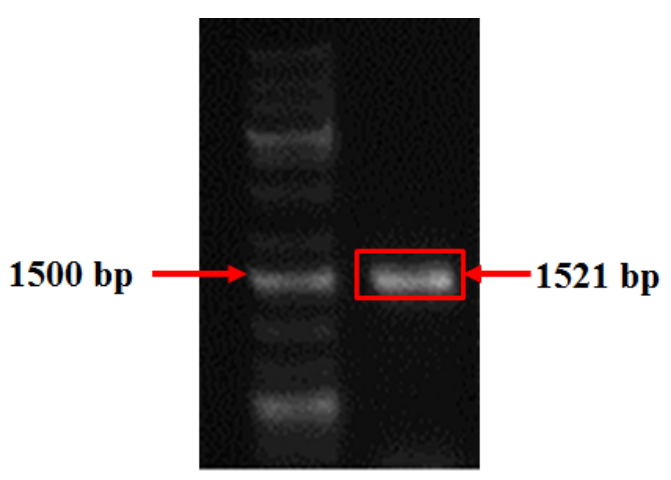

Fig. 10 PCR colony analysis of $P$. pastoris transforman

Observation under fluorescence microscopy revealed that transformed $P$. pastoris cell exhibited green fluorescene at the cell-surface of $P$. pastoris transformants (Fig. 11). The fusion protein was constructed with a hexa-His at the $\mathrm{N}$ terminal of gene. Hexa-His is widely used in production of protein to facilitate purification and detection of the desired 
protein [52]. To For detection of the protein on the cell surface, it was confirmed by immunofluoresence labeling of transformed cells and then analyzed by fluorescence microscopy. The observed fluorescene in the cell surface indicated that hexa-His and the desired protein were localized and displayed on the cell surface. The fuctionality of protein L-AI was validated by fluorescence microscopy of the $P$. pastoris transformants. Localization of fusion protein was visualized using FITC (fluorescein isothiocyanate)conjugated rabbit polyclonal antibody to $\mathrm{His}_{6}$ tag (Abcam). The FITC fluorescene signal was detected at the cell surface from the His-tag labeling of the fusion protein, confirming successful membrane localization of fusion protein.

A.
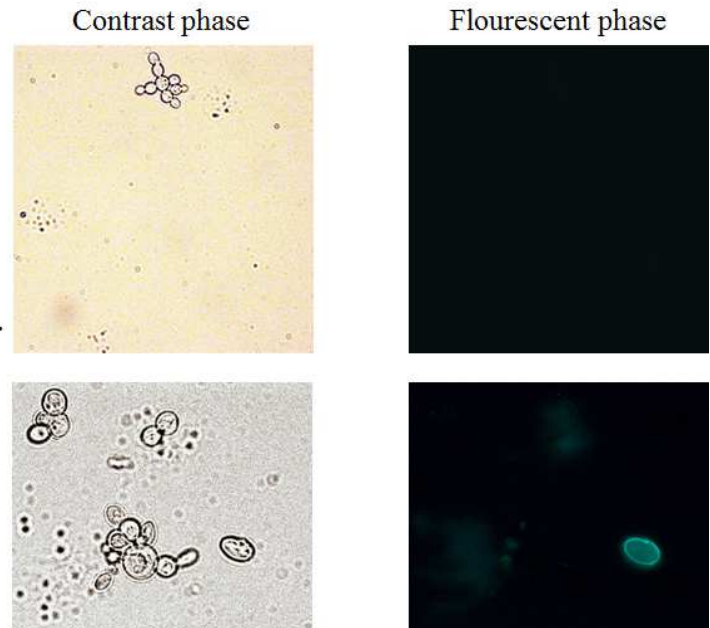

B.

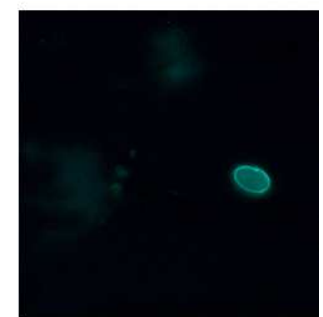

Fig. 11 Confocal microscopy of transformed and non transformed $P$ pastoris cells on the contrast (left) and fluorescent (right) phases. A: non transformed cells as control; B: transformed cells show fluorescene on the surface cell.

To confirm the protein was expressed on the cell surface of $P$. pastoris, it was detected by immuomagnetic technique using Pure Proteome ${ }^{\mathrm{TM}}$ Nickel Magnetic Beads combine with FITC-conjugated rabbit polyclonal antibody to $\mathrm{His}_{6}$ tag (Abcam). This magnetic beads can be used to screening and purify polyhistidine-tagged recombinant protein. It has developed para-magnetic affinity media for the purification of recombinant, His-tagged protein based on the well established nickel ion/histidine interaction. Observation under fluorescence microscopy revealed that transformed $P$. pastoris cell attached to the surface of beads and exhibited green fluorescene at the $P$. pastoris recombinant cells on surface of Pure Proteome ${ }^{\mathrm{TM}}$ Nickel Magnetic Beads (Fig. 12).

Polyacrilamide gel electrophoresis and hybridization analysis support the results of an observational analysis of hexa-His and desired protein under the microscope. Sodium dodecyl sulfate polyacrylamide gel electrophoresis (SDSPAGE) is used for analysis of soluble and insoluble protein. Analysis of the protein profile of the cell-free supernatant showed several bands of protein with molecular weights different (Fig. 13). The protein bands are the secreted protein of $P$. pastoris during ongoing overproduction.

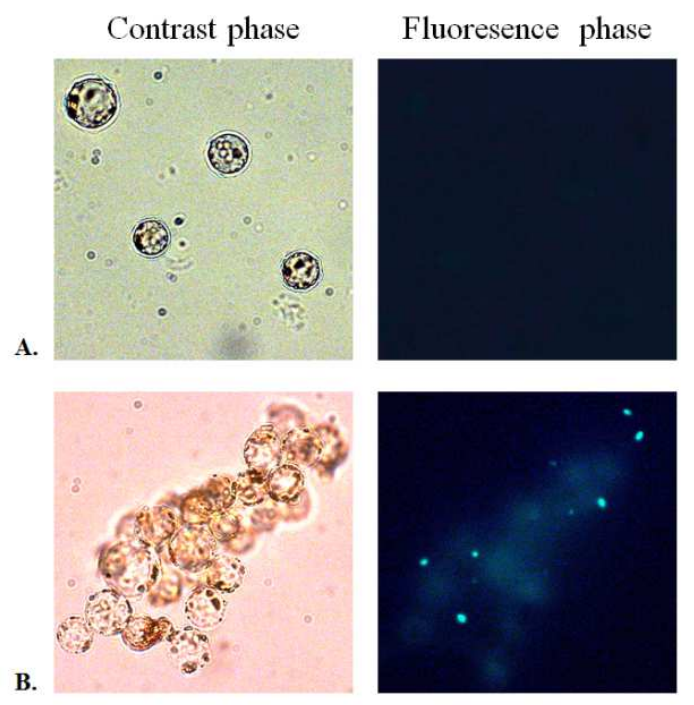

Fig. 12 Microscopic observation of interaction between cells, magnetic beads and antibody fluorescence on the contrast (left) and fluorescent (right) phases. A: non transformed cells as control; B: transformed cells bind to magnetic beads and show fluorescene on the surface cell.

Characterization of protein based on molecular weight using SDS-PAGE indicates that L-AI recombinant has a molecular weight approximately $91 \mathrm{kDa}$, while the molecular weight of native protein is $56 \mathrm{kDa}$. Differences in molecular weight due to the additional fragments of His-Tag, Flag-Tag, and $\alpha$-Agglutinin located at the C-terminal end of L-AI.

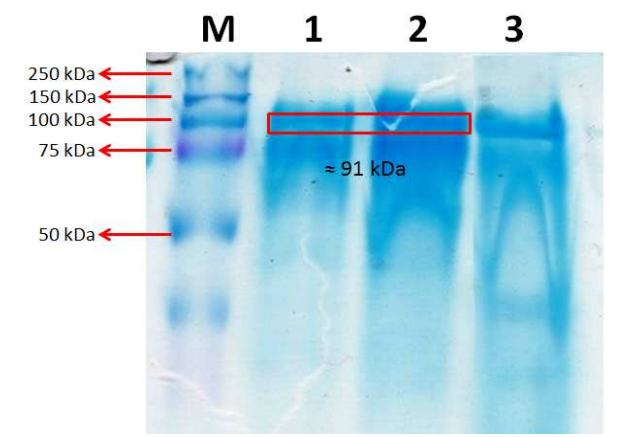

Fig. 13 Analysis of recombinant protein by SDS-PAGE. Lane M: Prestained Protein Standards; Lane 1: Recombinant not induced; Lane 2: Recombinant induced; Lane 3: Wildtype not induced.

\section{CONCLUSIONS}

The fusion gene araA has been successfully incorporated into the vector pJ912-AG $\alpha$ and confirmed by sequencing. The fusion gene was successfully transformed in genome of $P$. pastoris. The fusion protein was expressed on the cell surface of $P$. pastoris.

\section{ACKNOWLEDGMENT}

We would like to thank Dr. Budi Saksono for the source of GS araA gene, Yuliawati, M.Sc. and Aminah for technical assistant in $P$. pastoris handling. 


\section{REFERENCES}

[1] P. Kim, "Current studies on biological tagatose production using Larabinose isomerase: a review and future perspective", Appl. Microbiol. Biotechnol., vol. 65, pp. 243-249, Jul. 2004.

[2] E. Troyono, I. Martinez-Castro, and A. Olano, "Kinetics of galactose and tagatose formation during heat-treatment of milk", Food Chem., vol. 45, pp. 41-43, 1992.

[3] M. R. Mendoza, A. Olano, and M. Villamiel, "Chemical indicators of heat treatment in fortified and special milks", J. Agric. Food Chem., vol. 53, pp. 2995-2999, Apr. 2005.

[4] G. V. Levin, "Tagatose, the new GRAS sweetener and health product", J. Med. Food, vol. 5, pp. 23-36, May. 2002.

[5] D. K. Oh, "Tagatose: properties, applications, and biotechnological processes", Appl. Microbiol. Biotechnol., vol. 76, pp. 1-8, Aug. 2007.

[6] Y. Ishida, T. Kamiya, H. Itoh, Y. Kimura, K. Izumori, "Cloning and characterization of the D- tagatose 3-epimerase gene from Pseudomonas cichorii ST-24”, J. Ferment. Bioeng., vol. 83, pp. 529534, March. 1997.

[7] M. Rollini and M. Manzoni, "Bioconversion of D-galactitol to tagatose and dehydrogenase activity induction in Gluconobacter oxydans", Process Biochem., vol. 40, pp. 437-444, Jan. 2005.

[8] H. J. Kim, E. K. Hyun, Y. S. Kim, Y. J. Lee, and D. K. Oh, "Characterization of an Agrobacterium tumefaciens D-psicose-3epimerase that converts D-fructose to D-psicose", Appl. Environ. Microbiol., vol. 72, pp. 981-985, Feb. 2006.

[9] M. J. Patel, A. T. Patel, R. Akhani, S. Dedania, D. H. Patel, "Bioproduction of D-Tagatose from D-Galactose Using Phosphoglucose Isomerase from Pseudomonas aeruginosa PAO1", Appl Biochem Biotechnol., vol. 179, pp. 712-727, Jul. 2016.

[10] P. Cheetham and A. Wootton, "Bioconversion of D-galactose into Dtagatose", Enzyme Microb. Technol., vol. 15, pp. 105-108, Feb. 1993.

[11] S. Liu, J. Wiegel, and F. C. Gherardini, "Purification and cloning of a thermostable xylose (glucose) isomerization with an acidic $\mathrm{pH}$ optimum from Thermoanaerobacterium strain JW/SLYS 489", J. Bacteriol., vol. 178, pp. 5938-5945, Oct. 1996.

[12] M. Rhimi and S. Bejar, "Cloning, purification and biochemical characterization of metallic-ions independent and thermoactive Larabinose isomerase from the Bacillus stearothermophilus US100 strain”, Biochem. Biophys. Acta, vol. 1760, pp. 191-199, Feb. 2006.

[13] E. S. Jung, H. J. Kim, and D. K. Oh, "Tagatose production by immobilized recombinant Escherichia coli cells containing Geobacillus stearothermophilus L-arabinose isomerase mutant in a packed-bed bioreactor", Biotechnol. Prog., vol. 21, pp. 1335-1340, Jul-Aug. 2005.

[14] H. J. Kim and D. K. Oh, "Purification and characterization of an Larabinose isomerase from an isolated strain of Geobacillus thermodenitrificans producing D-tagatose", J. Biotechnol., vol. 120, pp. 162-173, Nov. 2005.

[15] J. W. Kim, Y. W. Kim, H. J. Roh, H. Y. Kim, J. H Cha, K. H. Park, and C. S. Park, "Production of tagatose by a recombinant thermostable L-arabinose isomerase from Thermus sp. IM6501". Biotechnol. Lett., vol. 25, pp. 963-967, Jun. 2003.

[16] F. Jørgensen, O. C. Hancen, and P. Stougaard, "Enzymatic conversion of D-galactose to D-tagatose: heterologous expression and characterization of Thermostable L-arabinose isomerase from Thermoanaerobacter mathranii", Appl. Microbiol. Biotechnol., vol. 64, pp. 816-822, Jun. 2004.

[17] W. Mei, L. Wang, Y. Zang, Z. Zheng, J. Ouyang, "Characterization of an L-arabinose isomerase from Bacillus coagulans NL01 and its application for D-Tagatose production", BMC Biotechnology., vol. 16, pp. 55-65, June. 2016

[18] R. M. Manzo, M. de Sousa, C. L. Fenoglio, L. R. B. Gonçalves, E. J. Mammarella, "Chemical improvement of chitosan modified beads for the immobilization of Enterococcus faecium DBFIQ E36 L arabinose isomerase through multipoint covalent attachment approach", J Ind Microbiol Biotechnol., vol 42, pp. 1352-1340, August. 2015.

[19] N. Bortone and M. Fidaleo, "Immobilization of the recombinant (His)6-tagged L-arabinose isomerase from Thermotoga maritima on epoxy and cupper-chelate epoxy supports", FOOD BIOPROD PROCESS., vol. 95, pp. 155-162, May. 2015.

[20] S. J. Lee, D. W. Lee, E. A. Choe, Y. H. Hong, S. B. Kim, B. C. Kim, Y. R. Pyun, "Characterization of a thermoacidophilic L-arabinose isomerase from Alicyclobacillus acidocaldarius: Role of Lys-269 in
pH optimum”, Appl. Environ. Microbiol., vol. 71, pp. 7888-7896, Dec. 2005.

[21] H. J. Kim, S. A. Ryu, P. Kim, and D. K. Oh, "A feasible enzymatic process for D-tagatose production by an immobilized thermostable L-arabinose isomerase in a packed-bed bioreactor", Biotechnol. Prog., vol. 19, pp. 400-404, Mar-Apr. 2003.

[22] S. A. Ryu, C. S. Kim, H. J. Kim, D. H. Baek, and D. K. Oh "Continous D-tagatose production by immobilized thermostable Larabinose isomerase in a packed-bed bioreactor", Biotechnol. Prog., vol. 19, pp. 1643-1647, Nov-Dec. 2003.

[23] C. H. Wu, I. J. Liu, R. M. Lu, H. C. Wu, "Advancement and application of peptide phage display technology in biomedical science", J Biomed Sci.,vol. 23, pp. 8, Jan. 2016.

[24] Y. Tan, T. Tian, W. Liu, Z. Zhu, C. J. Yang, "Advance in phage display for bioanalysis”, Biotechnol J., vol. 11, pp. 732-745, Jun. 2016.

[25] K. C. Ko, B. Lee, D. E. Cheong, Y. Han, J. H. Choi, J. J. Song, "Bacterial cell surface display of a multifunctional cellulolytic enzyme screened from a bovine rumen metagenomic resource', J. Microbiol. Biotechnol., vol. 25, pp. 1835-1841, Nov. 2015.

[26] C. Michon, P. Langella, V. G. H. Eijsink, G. Mathiesen, J. M. Chatel, "Review: Display of recombinant protein at the surface of lactic acid bacteria: strategies and application", Microb Cell Fact., vol 15, pp. 70-85, May. 2016.

[27] Z. Liu, K. Inokuma, S. H. Ho, R. dee Haan, T. Hasunuma, W. H. van Zyl, A. Kondo, "Combined cell-surface displayand secretion-based strategies for production of cellulosic ethanol with Saccharomyces cerevisiae", Biotechnol Biofuels., vol 8, pp. 62-73, Sept. 2015.

[28] T. Tanaka and A. Kondo, "Minireview: Cell-surface display of enzymes by the yeast Saccharomyces cerevisiae for synthetic biology”, FEMS Yeast Res., vol 15, pp. 1-9, Jani. 2015.

[29] K. Soga, H. Abo, S. Y. Qin, T. Kyoutou, K. Heimori, H. Tateno, N. Matsumoto, J. Hirabayashi, K. Yamamoto, "Mammalian cell surface display as a novel method for developing engineered lectins with novel characteristics", Biomolecules., vol. 5, pp. 1540-1562, Jul. 2015 .

[30] G. P. Smith, "Filamentus fusion phage: novel expression vectors that display cloned antigens on the virion surface", Science., vol. 228, pp. 1315-1317, Jun. 1985

[31] D. Y. Tsai, Y. J. Tsai, C. H. Yen, C. Y. Ouyang, Y.C. Yeh, "Bacterial surface display of metal binding peptides as whole-cell biocatalysts for 4-nitroaniline reduction", RSC Adv., vol. ,5, pp. 87998-88001, Oct. 2015.

[32] M. R. Smith, E. Khera, F. Wen, "Engineering novel and improved biocatalysts by cell surface display", Ind. Eng. Chem. Res., vol. 54, pp. 4021-4032, Jan. 2015

[33] N. R. Mohamad, N. H. C. Marzuki, N. A. Buang, F. Huyop, R. A Wahab, "An overview of technologies for immobilization of enzymes and surface analysis techniques for immobilizied enzymes", Biotechnol. Biotechnol. Equip., vol. 29, pp. 205-220, Mar.2015.

[34] T. Tanaka, R. Yamada, C. Ogino, and A. Kondo, "Recent developments in yeast cell-surface display toward extended applications in biotechnology", Appl. Microbiol. Biotechnol., vol. 95, pp.577-591, Aug. 2012.

[35] Kondo and M. Udea, "Yeast cell-surface display-applications of molecular display”, Appl. Microbiol. Biotechnol., vol. 64, pp. 28-40, Mar. 2004.

[36] M. Schreuder, S. Brekelmans, H. van den Ende, and F. M. Klis, "Targeting of a heterologous protein to the cell wall of Saccharomyces cerevisiae", Yeast, vol. 9, pp. 399-409, Apr. 1993.

[37] T. Tahino, H. Fukuda, and A. Kondo, "Construction of a Pichia pastoris cell-surface display system using Flo1p anchor system", Biotechnol. Prog., vol. 22, pp. 989-993, Jul-Aug. 2006.

[38] R. Daly and M. T. W. Hearn, "Expression of heterologous proteins in Pichia pastoris: a useful experimental tool in protein engineering and production”, J. Mol. Recognit., vol. 18, pp. 119-138, Mar-Apr. 2005.

[39] M. Mergler, K. Wolf, and M. Zimmermann, "Development of a bisphenol A-adsorbing yeast by surface display of the Kluyveromyces yellow enzyme on Pichia pastoris", Appl. Microbiol. Biotechnol., vol. 63, pp. 418-421, Jan. 2004.

[40] M. V. H. Moura, G. P. de Silva, A. C. O. Machado, F. A. G. Torres, D. M. G. Freire, R. V. Almeida, "Displaying Lipase B from Candida antartica in Pichia pastoris using the yeast surface display approach: prospection of a new ancor and characterization of the whole cell biocatalyst", PLoS One., vol. 10:e0141454, Oct. 2015.

[41] W. Li, H. Shi, H. Ding, L. Wang, Y. Zhang, X. Li, F. Wang, "Cell surface display and characterization of Rhizopus oryzae lipase in 
Pichia pastoris using Sed1p as an anchor protein", Curr Microbiol., vol. 71, pp. 150-155, Jul. 2015.

[42] V. Ananphongmanee, J. Srisala, K. Sritunyalucksana, C. Boonchird, "Yeast surface display of two protein previously shown to be protective against white spot syndrome virus (WSSV) in shrimp", PLoS One., vol 10: e0128764, Jun. 2015

[43] J. Sambrook, E. F. Fritsch, and T. Maniatis, "Molecular cloning: a laboratory manual", 3rd ed., Ed., New York, USA: Cold Spring Harbor Laboratory, 1989.

[44] A. Berlec, P. Zadravec, Z. Jevnikar, B. Štrukelj, "Identification of candidate carrier protein for surface display on Lactococcus lactis by theoretical and experimental analyses of the surface proteome', Appl. Environ. Microbiol., vol. 77, pp. 1292-1300,Feb. 2011.

[45] U. K. Laemmli, "Cleavage of structural proteins during assembly of head of bacteriophage T4", Nature..,vol. 227, pp. 680-685, August. 1970

[46] D. Fitriani and B. Saksono, "Cloning of araA gene encoding Larabinose isomerase from marine Geobacillus stearothermophilus isolated from Tanjung Api, Poso, Indonesia”, HAYATI J Biosci., vol 17, pp 58-62, June. 2010
[47] J. L. Cereghino and J. M. Cregg, "Heterologous protein expression in the methylotrophic yeast Pichia pastoris", FEMS Microbiol. Rev., vol. 24, pp. 45-66, Jan. 2000.

[48] M. Romanos, "Advances in the use of Pichia pastoris for high-level expression”, Curr. Opin. Biotechnol. Vol. 6, pp. 527-533. 1995.

[49] D. R. Higgins, K. Busser, J. Comiskey, P. S. Whittier, T. J. Purcell, J. P. Hoeffler, "Small vectors for expression based on dominant drug resistance with direct multicopy selection", Methods Mol. Biol., vol. 103, pp. 41-53, Feb. 1998.

[50] J. M. Cregg, K. R. Madden, K. J. Barringer, G. Thill, and C. A. Stillman, "Functional characterization of the two alcohol oxidasegenes from the yeast, Pichia pastoris", Mol. Cell Biol., vol. 9, pp. 1316-1323, Mar. 1989.

[51] K. Norden, M. Agemart, J. A. Danielson, E. Alexandersson, P. Kjelbom, U Johanson, "Increasing gen dosage greatly enhances recombinant expression of aquaporins in Pichia pastoris", BMC Biotechnology. Vol. 11, 47, May. 2011.

[52] E. Hochuli, H. Dőbeli, A. Scharcher, "New metal chelate adsorbent selective for proteins and peptides containing neighbouring histidine residues", J Chromatogr., vol. 411, pp 177-184, Dec. 1987. 